\title{
Rimpu As Culture on Creating Consumer Behavior of Mbojo
}

\author{
Sri Ernawati* \\ Institute of Economic Science of Bima \\ Bima, Indonesia \\ sriernawati.stiebima@gmail.com \\ Jaenab Jaenab \\ Institute of Economic Science of Bima \\ Bima, Indonesia \\ jaenab.stiebima@gmail.com
}

\author{
Mulyadin Mulyadin \\ Institute of Economic Science of Bima \\ Bima, Indonesia \\ mulyadinadvokat@gmail.com \\ Muhajirin Muhajirin \\ Institute of Economic Science of Bima \\ Bima, Indonesia \\ muhajirin.stiebima@gmail.com
}

\begin{abstract}
Every region in Indonesia has different tribes, customs, races and cultures. Mbojo tribe which is in a part of West Nusa Tenggara Province has a Rimpu culture. This is a local wisdom of the area in dressing by using the traditional cloth of Bima. This research aims to analyze the influence of culture, social class and sub-culture on consumer behavior. This research is quantitative in nature in which the survey is used as its approach. The data were collected through observation, questionnaire and literature research with a total sample of 100 people in which a purposive sampling technique was used. The results indicated that culture, social class and subculture influenced the creation of consumer behavior in Mbojo tribe.
\end{abstract}

Keywords - rimpu, culture, social class, sub-culture, consumer behavior

\section{INTRODUCTION}

Indonesia is a diverse country in terms of religion, race, culture, ethnicity and customs. This makes the State of Indonesia a rich country but from this diversity the Indonesian people always prioritize Bhineka Tunggal Ika which literary means Unity in Diversity so that differences can be put together. The habits of the Indonesian people to behave following the values that they adhered to for both religious and social-cultural values. The values contained in the socio-cultural community are the result of acculturation between individuals of the local community in the form of art, language, ceremonies, artifacts and values [1].

Basically, consumers have purchasing behaviors which are difficult to guess, with a variety of differences found in products and services of the same type but have brands and product specifications that are generally different so that consumers can quickly choose what they want [2]. Culture is basically inherent to a consumer. Thus, a culture may influence consumer behavior since it can be learned and helps to direct consumer behavior [3].

Companies are expected to see the state of the community so that the strategies can be accepted in which the products or services to be marketed will bring a desire to be owned. So, companies must be able to understand the desires and needs of consumers which are reflected in their behavior. Products and services to be marketed must be able to satisfy the desires of consumers. Thought and behavior can affect consumer behavior because culture is inherent and becomes one's identity [4].

In the Mbojo Tribe, there is a Rimpu culture which is a culture of dressing using Bima woven sarong which contains religious values. These values were strongly influenced by Arabs at the times when Arabs came to Bima for trading. Rimpu culture has been widely introduced at major events both locally, nationally and even internationally such as commemorating the anniversary of the Bima district government, Uma Lengge festival, Rimpu festival at Monas, the two-century Tambora festival, and most recently the Rimpu culture earned The Indonesia World Records with the category of most used Rimpu in Indonesia amounted to 20,165 people. This proves that culture has a multiplayer effect such as being able to raise the name of local government, increasing demand for Bima woven sarong and most importantly for preserving culture as a local wisdom inherited from the ancestors of the Mbojo Tribe community.

The urgency of this research is that culture can influence consumer behavior, culture can reflect consumer behavior in which consumers evaluate products based on the achievement of perceived cultural values. Consumer behavior involves their natural feelings and thoughts. Consumers must be able to think carefully in terms of purchasing decisions by considering the benefits obtained compared to the sacrifices incurred. In addition, consumers also make purchasing decisions because they want to be respected and valued [5]. The scope of this research is the culture of gaps in consumer behavior, by developing several variables such as culture, social class and subculture. The purpose of this research is to analyze the influence of culture, social class and sub-culture on consumer behavior.

\section{RESEARCH METHOD}

This research was conducted with a survey approach by using a questionnaire as a research instrument in which it was distributed on large and small populations This research was done in the Mbojo Tribe which is the administrative area of three local governments namely Bima Regency, Bima City and Dompu Regency [6]. The data were collected through observation, questionnaires and literature research. The population was all women in 
the research location with a sample of 100 people in which it was purposively chosen. Purposive sampling technique was used in order to set up a special characteristic which was intended to answer the research problems, namely the women consumers from Mbojo tribe that have bought Bima woven sarong to be used as Rimpa. The data were analyzed by using SPSS. The hypotheses in this study are as follows:

H1 : Culture influences the creation of consumer behavior

$\mathrm{H} 2$ : Social class is influential in the creation of Consumer Behavior

H3 : Sub-Culture influences the creation of consumer behavior

\section{RESULTS AND DISCUSSION}

In accordance with the statement that the regression equation model is considered appropriate if the regression equation has met the classical assumption test in which all data are normally distributed, all models are free from multicollinearity and heteroscedasticity. From the results of the analysis, the classical assumptions of this research are considered to meet the requirements so that the classical assumption is considered good and can be preceded.

\section{A. The Influence of Social Classes on Creating Consumer Behavior}

According to Schiffman et.al.. social class is an important variable in determining the shopping choice of the customers [7]. Different social classes have different perspectives on appropriateness, good fashion or taste.

The results of the $t$-test for the Social Class variable indicates that t-test result 5.114 is higher than the value of $\mathrm{t}$-table that is $1.98498(5.114>1.98498)$ with a significance value of $0,000(0,000<0.05)$, then the hypothesis "Social Class has an effect on in the creation of consumer behavior" is accepted. This research is in line with the research conducted by Ria Dwi Nugraheni which states that Social Classes influence Consumer Behavior (Study on home purchases at PERUM PERUMNAS Mojokerto branch in Madiun) [8].

\section{B. Influence of Subculture on the Creation of Consumer Behavior}

Sumarwan mentioned that consumers have a different lifestyle, this is proved by the existence of consumer goals in which most consumers express the values they hold to satisfy their needs [9]. Each culture consists of several smaller sub-cultures that provide more specific identification and socialization for their members. Subcultures include nationalities, religions, racial groups, and geographical areas. When sub-cultures grow big and rich enough, companies often design marketing programs specifically to serve them. It is not only concerning culture and sub-culture.

The results of the t-test for the Sub Culture variable indicates that $t$-test of 2,663 is higher than the value of the t-table that is $1,98498(2,663>1,98498)$ with a significance value of $0,000(0,009<0.05)$, then the hypothesis "SubCulture influences on the creation of Consumer Behavior" is Accepted. This result contradicts the research conducted by Mariani, et.al. which states that Sub-Culture does not influence students' behavior on buying traditional cakes in Surabaya [10].

\section{CONCLUSION}

The conclusion that can be drawn from this study is that Cultural Variables have an influence on the behavior of Mbojo Tribe consumers in which the Mbojo tribe community still considers that Rimpu is a culture that must be preserved continuously because it contains religious, moral, artistic and ethical values of dressing. The Social Class variable influences the Consumer Behavior of the Mbojo Tribe in which the community considers the quality of the woven fabric used is to reflect pride as individuals and their own norms. The Sub-Culture variable has an influence on the Consumer Behavior of the Mbojo Tribe in which some people consider that the Rimpu is the legacy of their ancestors and only the Mbojo community owns it.

This research implies that local governments within the Mbojo Tribe area, namely Bima City, Bima Regency and Dompu Regency, must synergize with one another to continuously preserve the culture of Rimpu through regional, national and international events so that the cultural heritage inherited by the ancestor may last. Also, the culture of Rimpu must be legitimized so that it could not be claimed by other regions or even other countries

\section{REFERENCES}

[1] K. Kussudyarsana, "BUDAYA DAN PEMASARAN Tinjauan Pengaruh Budaya terhadap Perilaku Konsumen," Benefit J. Manaj. dan Bisnis, vol. 12, no. 2, pp. 172-180, 2009.

[2] K. I. Pratiwi and K. Mandala, "Pengaruh Faktor Budaya, Sosial, Pribadi, Psikologis, dan Bauran Pemasaran Terhadap Keputusan Pembelian Kebaya Bordir Pada Jegeg Ayu Boutique di Kuta," E-Jurnal Manaj., vol. 4, no. 11, 2015.

[3] A. T. Dwicahyo, N. Adiarni, and M. Najamuddin, "Pengaruh Konsep Produk, Budaya Konsumsi, dan Keluarga Terhadap Perilaku Konsumen Mengkonsumsi Produk Kebab (Studi Kasus: Kebab Turki XXX)," Ind. J. Teknol. dan Manaj. Agroindustri, vol. 6, no. 1, pp. 8-14, 2017.

[4] E. Sulistyowati, "Motivasi dan Perilaku Konsumen Dalam Keputusan Pembelian Produk Industri Kerajinan Kulit Di Yogyakarta," J. Maksipreneur Manajemen, Koperasi, dan Entrep., vol. 2, no. 2, pp. 17-26, 2013.

[5] M. E. Saputri, "Perilaku Pembelian Online Produk Fashion Pada Zalora Indonesia," J. Sosioteknologi, vol. 15, no. 2, pp. 291-297, 2016.

[6] Sugiyono, Metode Penelitian Kuantitatif, Kualitatif dan R\&D. Bandung. Bandung: Afabeta, 2011.

[7] L. Schiffman, "G.., Kanuk, L., L. 2000. Consumer Behavior," Am. Prentice Hall Int. Inc, 2004.

[8] R. D. Nugraheni, "Pengaruh Kelas Sosial Terhadap Perilaku Konsumen (Studi Pada Pembelian Rumah Di Perum Perumnas Cabang Mojokerto Lokasi Madiun)," Equilib. J. Ilm. Ekon. dan Pembelajarannya, vol. 6, no. 1, pp. 80-85, 2018.

[9] U. Sumarwan, "Perilaku konsumen: Teori dan penerapannya dalam pemasaran," Bogor Ghalia Indones., 2011.

[10] M. S. Giantara and J. Santoso, "Pengaruh Budaya, Sub Budaya, Kelas Sosial, Dan Persepsi Kualitas Terhadap Perilaku Keputusan Pembelian Kue Tradisional Oleh Mahasiswa Di Surabaya," J. Hosp. dan Manaj. jasa, vol. 2, no. 1, pp. 111-126, 2014. 